\title{
Ethnic Identity and Constitutional Reprentative Governance in Nigeria
}

\author{
Aborisade Olasunkanmi \\ Ladoke Akintola University of Technology Ogbomoso, Ogbomoso, Nigeria \\ Email: aborisaderose@yahoo.com,Omoboy41@gmail.com
}

How to cite this paper: Olasunkanmi, A. (2019) Ethnic Identity and Constitutional Reprentative Governance in Nigeria. Open Access Library Journal, 6: e5487. https://doi.org/10.4236/oalib.1105487

Received: May 22, 2019

Accepted: July 1, 2019

Published: July 4, 2019

Copyright () 2019 by author(s) and Open Access Library Inc.

This work is licensed under the Creative Commons Attribution International License (CC BY 4.0).

http://creativecommons.org/licenses/by/4.0/ (c) (i) Open Access

\begin{abstract}
The work focuses on ethnic identity and constitutional representative governance in Nigeria and how it has been aided or impeded by ethnic politics. Democracy, in the liberal perspective, is government by popular representation; a form of government in which the supreme power is retained by the people, but is indirectly exercised through a system of representation and delegated authority periodically renewed; a constitutional representative government. Today in Nigeria, there is serious rivalry among the ethnic groups over issues such as power and resource sharing formula, the fear of domination, uneven development and many more. It is clear that constitutional representative governance in Nigeria has fallen far below expectation, as primordial ethnic loyalties are still deep seated. Ethnic identity is seen as the major cause of this failure; it has sentence of Nigeria to pernicious and precarious situations. For Nigeria to move forward democratically, politics of identity remained unhealthy for her nascent democracy. Because, it is prone to ethnic domineering and unequal distribution of dividends of democracy.
\end{abstract}

\section{Subject Areas}

Politics

\section{Keywords}

Authority, Constitutional, Delegated, Democracy, Ethnic, Identity, Representation

\section{Introduction}

An ethnic group is a group of people whose members identify with each other through a common heritage, often consisting of a common language, culture, religion, ideology or geographical area. Ethnicity is a derivative of the ethnic group, it 
only occurs in situations involving more than one ethnic group and to fully understand the meaning of ethnicity, we have to first of all understand what ethnic group entails. This is particularly important because of the systemic differences in the definition of ethnicity across societies. Osaghae [1], notes that ethnicity is problematic phenomenon whose character is conflictual rather than consensual. He stressed that ethnicity is a conscious behaviour based on ethnic identity or loyalty in a competitive situation involving more than one such identity, which is aimed at furthering interests of the individual and/or group. So, ethnic group is an informal interest group whose members are distinct from the members of other ethnic groups within the larger society because they share kinship, religious and linguistics ties [2]. This means that ethnic groups are social formations, which are distinguished by the communal character of their boundaries [3]. By definition, ethnicity, it means the interactions among members of many diverse groups [3]. On the other hand, the term ethnicism denotes ethnic loyalty. This is a feeling of attachment to one's ethnic group [4]. Roth Barth [5] defines ethnicity as a unit of people perceiving themselves that are sharing common characteristics which distinguish them from others. This group must see themselves as having a kind of cultural background which is genuinely superior to those of others and judging others on the basis of the standard of judgment in one's own in-group. It is within this context that many scholars have equated ethnicity with racism [6] [7] [8]. To them, ethnicity is mere fiction invented by the Western world to divide and rule Africa. The invention of ethnicity no doubt wiped out the much needed unity and the cohesion to fight colonialism as one. It is therefore an ideological instrument just as racism to exploit and oppress the Africans [9] [10] [11] [12] [13]. There is no wonder why Miller described it aptly as a "concept" of composition, decomposition and recomposition [14].

Identity may be defined as a combination of socio-cultural characteristics which individuals share, or are presumed to share, with others on the basis of which one group may be distinguished from others. Identity is a group concept in the sense that it is based on traits which make individuals members of a group; such traits also provide responses to the question, "Who am I?" Identity has a combination of ethnic, religious, gender, class and other layers, all of which refer to the same person either in self-definition or as defined by others [15]. Identities could be used to create a universal identity, as in the case of nationalism and a search for a common identity in African countries, or more broadly, in Africa as a continent [16]. Identity is one of the most crucial needs identified by the basic needs theory because it is an extremely strong catalyst for social mobilization. Many scholars stress identity salience as a key factor in conflict. For example, Roth Bart and Cherubim [17], assert that identity relies on a common set of narratives, symbols, and a shared sense of group differences. For these scholars, causes of identity based violence often include the "shared normative commitments of the protagonists' groups, commitments that center on notions of in-group purity and out-group vice" [17]. This distinction between "us" and "them" represents a potential societal fracture. Elebeke [18] defined 
identity as a process located in the core of the individual and yet also in the core of his communal culture, a process which establishes, in fact, the identity of these two identities. Your identity is who you are. So, an identity crisis is when you either lose track of who you are or do not feel happy with who you are and want to change your life or restructure it. A major transformation in a person's personality and the way they do things may occur if they have an identity crisis.

Ethnic identity refers to a person's social identity within a large context based on membership in a cultural or social group. It refers to an individual's knowledge about his or her ethnic group, such as cultural traditions and history. Ethnicity as an identity inevitably occupies a great space within the political arena and also it is the easiest and most natural way for people to mobilize around basic human needs such as security, food, shelter, economic well-being, inequality, land distribution, autonomy, and recognition [19]. All these brought about a social identity where the minorities as well as the majority identify themselves as having some distinct features which separate them psychologically from other groups. Even in democratic institutions, ethnicity would create a bias in the process of elaborating social choice [20], and would decrease the weight of general interest in the determinants of votes. The mechanism at stake is thus the following: ethnic membership determines individual's identity, preferences and choices; since the ethnic group is different (and generally narrower) from the political group (the State or the nation), the definition of individual identity by ethnic determinants weakens the sense of collective interest that conditions the existence of an efficient democratic State. As argued by Osaghae [1], the scourge of ethnicity had been a common feature in the country's party politics and the drive towards achieving democracy. It is a fact that since the colonial era, Nigeria's national identity has been at odds with the more exclusive ethnic identities [21]. According to Nnoli [22] the history of ethnic politics in the country has shown that it is quite divisive. This divisiveness has plagued all efforts at national development, especially the national population's sense of solidarity, and its morale and commitment to hard work. It has generated tension and insecurity that have exploded into conflict and violence, notably the civil war of 1967-1970.

Our concern in this work is to examine the possible effect of ethnic identity on liberal democracy otherwise known as representative democracy. Democracy, in the liberal perspective, is government by popular representation; a form of government in which the supreme power is retained by the people, but is indirectly exercised through a system of representation and delegated authority periodically renewed; a constitutional representative government. With constitutional representative governance in mind, this paper interrogates how ethnic identity may have aided or impeded institutionalisation of democracy in the country.

\section{Ethnic Identity and Democratic Governance}

It is clear that democratic governance in Nigeria has fallen far below expectation and ethnic particularism is seen as the major cause of this failure that is what 
this section is all about.

The political parties in Nigeria were established based on ethnic rather than ideological orientation right from 1954 when we have three regions in Nigeria. The political parties in Nigeria then were more of ethnic based rather than national. There were Action Group in the Western Region, National Council of Nigeria Citizen in the Eastern Region and Norther People's Congress in the Northern Region. Several years after independence, political parties in Nigeria are not still National but Regional. This situation failed to produce the necessary ingredient for the enthronement of liberal democratic governance in Nigeria. The 2019 election in Nigeria feature 91 political parties, but the new things that happened to political atmosphere in Nigeria today are the issue of alliance. For example; Action Congress of Nigeria (CAN) and Congress for Progressive Change, both were regional parties but in their attempt to form a formidable force against the ruling government; agree to come together, negotiate their differences and then form a national party call All Progressive Congress (APC). They have succeeded in defeating the ruling People Democratic Party (PDP) in 2015 general election and also in 2019 general election. If the pendulum is maintaining the future of democratic governance in Nigeria may become certain.

Another noticeable fact is cultural affiliation. This has played a major role in Nigeria democracy. This has affected the emergence of a focus drive leader. At independence in 1960, Nigeria adopted British parliamentary model which was an uncomfortable marriage between Nigerian culture and British culture. The second republic made a giant stride by changing from parliamentary to presidential system of government which wasn't workable. It was the failure of this that led to another military coup in December 1983, what we are saying is that, there is a distinct and limited political culture which gives meaning to political process in a country, and such country must in her historical context learn and incorporate it. When a country does this, politically they have a focus. Nigeria need to search for appropriate culture that matches the condition and orientation of her citizen, borrowing or affiliating with any foreign culture may not help. Nigeria secure her independence on October $1^{\text {st }}, 1960$; for almost sixty years still searching for her bearing. I believe something radical need to be done about ethnic identity to give way for enthronement of democracy in the new millennium.

Politics of identity is prone to unequal distribution of wealth which most time aggravate political crisis. One section of the country providing about $90 \%$ of the annual total revenue of a country and the other parts are contributing insignificant percentage. The contributing sections were and still remained undeveloped, while all other parts remain constantly developing and beautifying every day. This situation is generating a lot of crisis in Nigeria today. This has been responsible for the militias' activities in the Niger Delta. This situation is worrisome. Should the purpose of one ethnic, social, political and economic group be done at the ruins of others? Will it not be of mere service to the development of Nige- 
ria, if all others ethnic groups are develop as well, more so when the bulk of the revenue come from the region. According to Ajah [23] national integration in Nigeria after independence was and still is not a choice rather it is a necessity.

The role of elite in Nigeria also affected her political system. According to Adesiyan and Segun [24], those Nigeria elite are willing to violate the rules of democratic gain and overstep normal bound of authority. Higley, claimed that; elite are "persons who, by virtue of their strategic locations in large or otherwise pivotal organizations and movements, are able to affect political outcomes regularly and substantially". This theory was popularized by Gaetano Mosca (1858-1941), Vilfredo Pareto (1848-1923), and Robert Michels (1876-1936). This theory explains the power dynamics and social relations surrounding the acquisition and preservation of state power within the democratic framework. It reveals the fundamental characters and realities of representative democracy, where the country was structure into powerless majority and powerful minority. The powerful minority are the elite that control the state power while the powerless majority are governed by the elites. In every societies elites are considered to have the capacity to possessed organizational competence and verse political knowledge necessary for steering the political statecraft in a democratic dispensation but they represent a negation of the key democratic principle of mass ownership of the governance process. This has made it almost impossible for the enthronement of democracy in Nigeria.

It is also necessary to note that one important factor that makes it easy for the elites to manipulate ethnicity to serve their parochial interest is the system of multi-party, single-member electoral process in Nigeria which encourages ethnic chauvinism. The case is so because most of the constituencies in Nigeria are conterminous with ethnic homeland. As such, it is easy for candidates to contest elections without any program but their ethnic credentials of being 'the son of the soil'. In this case, they utilize ethnic appeals and idioms to solicit votes, emphasizing the neglect of their respective ethnic groups of which they promise to rectify on assumption of office, thus promoting the 'us versus them' syndrome [25]. Today in Nigeria, politicians depended on their ethnic identity for vote. The just concluded 2019 presidential election in Nigeria polarize the country in to two, among the two leading political parties. In All Progressive Congress (APC) the presidential flag bearer is MuhammaduBuhari and the vice is Professor YemiOsibajo. Buhari is from the North while Osibajo is from the west. The flag bearer of People Democratic Party (PDP) Abubaker Atiku is from the north while his vice Obi is from the East. The two political parties count more on their ethnic enclave for vote more than national.

Prolong military rule in Nigeria has contributed in no small measure to the political divides. The military as an institution in Nigeria had jettisoned their role as a professional who should maintain and secure the territorial integrity of their country but instead taken over the government they are expected to protect. They rule by decree, though they claim that it is a legal document, but certainly not legitimate. In fact, decrees are instruments for terrorizing the poor 
and the weak, legitimating corruption and privatization of the state, and rationalizing the suffocating of civil society and subservient relationships with imperialism. Though the military in Nigeria have been disengaged from power, the effects of their past years of ruling the country have not left the country. Though, it is a fact that the military has left the scene for the civilian rule since 1999; the succeeding politicians have been behaving and acting like the military. The human right abuse still remains as before, they order and command like the military. In fact it has been the same military that retired from active service that put on the civilian regalia. What do you expect from a General turncivilian? To make the matter worst, many of this military turn civilian still pays their allegiance first to their ethnic enclave, forgetting that they belong to the whole Nigeria. The first administration of President Buhari testified to this. This situation continues to slow down the enthronement of democratic governance in Nigeria.

Another noticeable problem in Nigeria is inter party dispute. Right from Nigeria independence in 1960, inter party dispute policy has been rearing its ugly head of ten and often in the polity. For instance the first case of political violence that leads to serious inter party dispute started immediately after independence. The problem started with the elections conducted immediately after independence in the 1960s. In the Western Region political violence, popularly referred to as "operation wet e", were recorded from 1964 to 1965 that claimed many, lives. There was also political violence in parts of Northern Region that also claimed many lives, especially between supporters of the Northern People's Congress(NPC) and supporters of other parties, mainly the Northern Elements Progressive Union (NEPU) and Action Group. This led to the military coup of January 5, 1966, in which the then Prime Minister, Tafawa Balewa and Premiers Ahmadu Bello and LadokeAkintola, of the Northern and Western Regions, respectively were assassinated [26]. The aftermath of the military coup led to Nigerian Civil War 1966-1970 in which the Igbo tribes were almost exterminated. It was a reminiscence of what happened in Germany under Nazi regime and Rwandagenocide, in which a tribe was almost exterminated completely. These unfortunate incidences still continue in Nigeria; since electioneering campaign are almost base on ethnic line. The parties are ethnic related party. No national party; that has been the reason why the outcome of any elections always leads to serial dispute that threatened the stability of the country. According to [22], instead of building across ethnic and religious differences, Nigerian politicians manipulate them for their selfish interests in political power and wealth. The truth, he submits, is that Nigeria is unfortunate to have bred politicians whose field of vision does not extend beyond their personal interest for power and wealth that has been the reason while the conduct of election over the years have not produced credible result due to politics of identity and cultural affiliations. Winner-takes all politics that defines the liberal democratic model, carries with it electoral crisis. It is a system where the winner at election takes all and the loser is vanquished. Since everybody want to be in the mainstream of the subsisting politics, elections become a "do or die" affair. I can't imagine how 
many billion went into election campaign in Nigeria. I often wonder where they are getting the money being spent during the election period in Nigeria. Money for poster, for vehicle used, for staff, for touts and so on. In this context, managers of the electoral processes cannot be above board because the pressure, from the system is too enormous for anyone to play by the rules because all the parties are ready to have their ways by all means. Tell me how would any party that scales through these contest that is open to other earn the respect of others.

Leadership deficit is another important dilemma of Nigeria, BabangidaAliyu [27] opines that leadership deficit has over the years exposed Nigeria to high-level of corruption, bad governance, political instability and a cyclical legitimacy crisis. In an ideal society, leaders are expected to be role model. But the problem with Nigeria has remained the issue of bad leadership. Our leaders lack discipline and the citizens are following suit. Nigerian leaders have always been known for not obeying the constitution, since the constitution itself lacks merit. The colonialists have already set in place a bad example of governance, but Africa lack good leadership that will confront this dilemma and thus take Africa out of its debilitating condition [28]. Leadership is observed to be the most critical, such that many depict the continent as "a faraway place where good people go hungry, bad people run government, and chaos and anarchy are the norm" [29]. More so, it has been rightly observed that under "the various oppressive authoritarian regimes which Africa countries have had the misfortune to chafe under for the greater part of its post-colonial history, Africans have been treated to a bastardization of constitutionalism and growing impotence of the judiciary in the face of countless acts of impunity, executive lawlessness and economic brigandage by praetorian guards that had imposed themselves on the political landscape of the nation" [30]. The dearth of good leadership in postcolonial Africa is inversely proportional to the widespread poverty, not only of ideas about running the societies and states, but also the impoverishment of the populace [28]. Consequently, national development has been slow and the political environment uncertain, the enthronement of constitutional democratic governance remained a mirage.

\section{Conclusion}

Ethnic identity has affected the enthronement of democracy in Nigeria. Effort has been made by the leaders in this country to see that Nigeria moved and developed in line with the acceptable democratic norms all over the world but citizen allegiance to their ethnic enclave remained the stopping gap. For Nigeria to move forward democratically, politics of identity remained unhealthy for her nascent democracy; because, it is prone to ethnic domineering and unequal distribution of dividends of democracy. Nigerian should accept and inculcate the spirit of patriotism. The nation should be taken first before any other sectional interest. Minorities and other oppressed groups should strive and promote their specific interests through practical involvement in national and grassroots or- 
ganization within the limits of democratic principles. There should also be a deliberate program of political and social reorientation of the entire citizenry. Such political and social orientation will go a long way in changing the negative stereotypes and negative values that have characterized Nigerians.

\section{Conflicts of Interest}

The author declares no conflicts of interest regarding the publication of this paper.

\section{References}

[1] Osaghae, E.E. (1994) Ethnicity and Its Management in Africa: The Democratization Link. Malt House Press Ltd., Lagos.

[2] Cohen, A. (1974) Urban Ethnicity. Taristock Publications Ltd., London.

[3] Nnoli, O. (1978) Ethnic Politics in Nigeria. Fourth Dimension Publishing Co. Ltd., Enugu.

[4] Pepple, I.A. (1985) Ethnic Loyalty and National Identification.

[5] Rothbarth, D. and Cherubin, R. (2009) Causation as a Core Concept in Conflict Analysis. In: Dennis, J. and Sandole, D., Eds., Handbook of Conflict Analysis and Resolution, Routledge, London and New York, 59-70. https://doi.org/10.4324/9780203893166.ch4

[6] Appiah, A. (1986) The Uncompleted Argument: Dubois and the IIlusion of Race. In: Gates, H.L., Ed., Rate, Writing and Difference, Chicago University Press, Chicago, 32 .

[7] Mudimbe, V. (1998) The Invention of Africa. Indiana University Press, Bloomington.

[8] Owolabi, K.A. (2003) Fictional Tribes and Tribal Fictions. Ethnicity, Ethnocentrism and the Problem of "Other" in Africa. PEFS Monograph New Series No. 4, John Archers Publishers, Ibadan.

[9] Bamisaye, A. (1976) Ethnic Politics as an Instrument of Unique Socio-Economic Development in Nigeria's First Republic. In: Sanda, A. O., Ed., Ethical Relations in Nigeria, Caxton Press Ltd., Ibadan, 67.

[10] Michels, R. (1968) Political Parties. Illnoss Free Press, Glencoe.

[11] Mill, W. (1956) The Power Elite. Oxford University Press, New York.

[12] Ekeh, P.P. (1975) Colonialism and the Two Public in Africa: A Theoretical Statement. Comparative Studies in Society and History, 17, 91-112. https://doi.org/10.1017/S0010417500007659

[13] Focault, M. (1979) Discipline and Punish. Vintage Press, New York.

[14] Miller, C.L. (1991) Theories of Africans: Franco Wine Literature and Anthropology in Africa. University of Chicago Press, Chicago.

[15] Alubo, O. (2009) Citizenship and Identity Politics in Nigeria. In: Conference Proceedings on Citizenship and Identity Politics in Nigeria, CLEEN Foundation, Lagos, $1-4$.

[16] Kagwanja, P. (2003) Globalising Ethnicity, Localizing Citizenship: Globalisation, Identity Politics and Violence in Kenya's Tana River Region. Africa Development, 28, 112-152. https://doi.org/10.4314/ad.v28i1.22171 
[17] Reynoids, N.B. (1993) The Ethnical Foundations of Constitutional Order: A Conventionalist Perspective. Const Pol. Econ., 4, 79.

[18] Elebeke, E. (2010) Identify Crisis: Who Really Are Nigerians? (Central Database) Export Highlight Nation's Identity Management Crisis at CTO May 12, 2010.

[19] Kelman, H. (2007) Social-Psychological Dimensions of International Conflict. In: Zartman, I.W., Ed., Peace-Making in International Conflict. Methods and Techniques, United States Institute of Peace, Washington DC, 64-79.

[20] Robinson, J. (2001) Social Identity, Inequality and Conflict. Economics of Governance, 2, 85-99. https://doi.org/10.1007/PL00011021

[21] Azeez, A. (2009) Ethnicity, Party Politics and Democracy in Nigeria: Peoples Democratic Party (PDP) as Agent of Consolidation? Studies of Tribes and Tribals, 7, 1-9. https://doi.org/10.1080/0972639X.2009.11886588

[22] Nnoli, O. (2007) Political Parties and National Diversity. In: Oculi, O. and Nasidi, Y., Eds., Brain Gain for the African Renaissance: Issues in Governance, the Ahmadu Bello University Press Limited, Kaduna, 64.

[23] Ajah, M. (2006) Nigeria’s Stability Impacts Positively on Africa. Daily Trust, 15, 9.

[24] Adesiyan, V.A. and Segun, O. (2013) A Review of the Dynamics of Elite Recruitment, Granting Elite and Its Implications on Nigeria Political Space. International Journal of Development Studies, 7, 21.

[25] IDEA (2000) Democracy in Nigeria: Continuing Dialogue for Nation Building. Capacity Building Series Number 10, International IDEA, Stockholm.

[26] Buhlam, J. (1942) The Managerial Revolution. Pitman, New York.

[27] Aliyu Babangida, M. (2012) Nigeria's Unity and Regional Socio-Political Groups: Influence and Impact of the Northern States Governors' Forum. Chatham House, London.

[28] Afolayan, A. (2009) Poverty as Statecraft: Preliminary Reflections on African Leadership. Lumina, 20, 1.

[29] Thomson, A. (2002) An Introduction to African Politics. 2nd Edition, Routledge, London and New York.

[30] Oyebode, A. (2005) The Challenges of Building a Virile Democratic Nation in Critical Issues on Sustainable Democracy and Development: Nigerian Perspective. Leadership Watch, 49-61. 